\title{
Diuretic Activity of the Aqueous Extract Leaves of Crassocephalum crepidioides (Asteraceae) in Rats
}

\section{Ntchapda Fidèle $^{1 *}$, Talla Ernest Rodrigue ${ }^{1}$, Bonabe Christian ${ }^{1}$, Kemeta Azambou David Romain ${ }^{1}$ and Talla Emmanuel ${ }^{2}$}

\author{
${ }^{1}$ Department of Biological Sciences, ${ }^{2}$ Department of Chemistry, Faculty of Science, University \\ of Ngaoundéré, Cameroon, Po Box 454 \\ *Corresponding author
}

\section{Keywords}

Crassocephalum crepidioides,

Diuretic and saluretic activities, Urinary volume, Urinary $\mathrm{pH}$, Electrolytes

Article Info

Accepted:

20 March 2019

Available Online:

10 April 2019

\section{A B S T R A C T}

Crassocephalum crepidioides is a medicinal plant used in west and central Africa, not only as leguminous crop, but also to treat high blood pressure in particular. The objective of this work was to evaluate the diuretic activity of aqueous leaves extract of $C$. crepidioides in the treatment of high blood pressure as claimed by traditional healers. Rats both male and female were used to evaluate the diuretic activity. C. crepidioides was administered to rats at $25,50,75,100$ and $125 \mathrm{mg} / \mathrm{kg}$. The volume of urine was measured after $3,6,12$ and $24 \mathrm{~h}$ following there administration of the aqueous extract. The two positive control groups received Furosemide and Hydrochlorothiazide amiloride respectively, whereas the negative control group received distilled water $(1 \mathrm{ml} / 100 \mathrm{~g}$ of body weight). The urinary and blood concentrations of creatinine, urea, ALAT, ASAT and electrolytes $\left(\mathrm{Na}^{+}, \mathrm{k}^{+}, \mathrm{Cl}^{-}\right)$ were evaluated using a spectrophotometer. The significant increase of diuresis was accompanied by that of electrolytes excretion $\left(\mathrm{Na}^{+}, \mathrm{k}^{+}, \mathrm{Cl}^{-}\right)$, food and water consumption, creatinine and urea excretions. The increase in elimination of $\mathrm{Na}^{+}, \mathrm{k}^{+}, \mathrm{Cl}^{-}$induced by the extract provoked the alkalinization of urine. In the blood, a significant increase in the rates of electrolyte and urea, as well as a decrease in transaminase rate was noticed. However, no significant change was observed as far as the body weight and temperature, the $\mathrm{pH}$ of urine and the rate of creatinine serous in the animals treated with the aqueous extract of $C$. crepidioides. This work strongly indicated that $C$. crepidioides possesses a diuretic activity thus justifies its utilization by traditional healers for the cure of high blood pressure.

\section{Introduction}

Cardiovascular diseases (CVD) are diseases affecting the heart and blood vessels (veins and arteries). These diseases are the leading cause of death in the world. More people die each year from cardiovascular diseases than from any other deseases ${ }^{1}$. An estimated 17.5 million deaths from cardiovascular diseases are responsible for $31 \%$ of total global mortality $^{2}$. In CVD, there are several pathologies amongst which are; obesity, heart 
rhythm disorders, aneurysm, hypertension (High blood pressure), infarction and many others. In addition to these pathologies, we also have risk factors that are classified into two categories: non-modifiable risk factors (gender, age, family history) and modifiable risk factors (hypertension, dyslipidemia, overweight, tobacco, alcohol, diabetes). High blood pressure is not only a disease, but it is also an important risk factor for the development of other cardiovascular diseases ${ }^{3}$.

High blood pressure is an abnormal rise in arterial wall pressure (systolic blood pressure $\geq 140 \mathrm{mmHg}$ and / or diastolic blood pressure $\geq 90 \mathrm{mmHg})^{4}$. It is a cardiovascular disease system that has reached worrying proportions $^{5}$. Recent data from the WHO indicate that nearly one billion people around the world suffer from this disease. Out of 972 million hypertensive patients, $34.3 \%$ come from developed countries and $65.7 \%$ from developing countries, as a result of inadequate hygienic practices ${ }^{6}$. Given these high statistics, it is therefore imperative to find treatments to counteract this great killer.

In general, the management of hypertension is a lifelong process ${ }^{7}$, the treatment reduces mortality and cardiovascular morbidity ${ }^{8}$. Six classes of drugs, called antihypertensives, are used for the modern treatment of hypertension among which diuretics are the oldest and best evaluated drugs. The expensive cost of these antihypertensive drugs, their undesirable side effects, as well as the increase in poverty are among other reasons that lead patients to abandon conventional health centers for the benefit of traditional medicine ${ }^{9}$. In order to promote the diversity of plant species of Cameroon, a set of questionnaires was given to the traditherapists of the Mifi Department, in the west region Cameroon in 2017. Following the survey, several plants were partly listed for the treatment of hypertension.
Considering the repeated use of $C$. crepidioides by several local healers, we decided to conduct research on this plant.

Crassocephalum crepidioides is a plant of the Asteraceae family, for which its leaves and stems are tender and fleshy mucilaginous, and are used not only in the treatment of cardiovascular diseases (e.g. arterial high blood pressure), but also as a vegetable in soups in the West and Central Africa. It is also indicated as an antibacterial plant ${ }^{10}$. It is a powerful antioxidant and protects against hepatotoxicity ${ }^{11}$. It has been shown to have anti-tumor activity ${ }^{12}$. The present study aims at evaluating the diuretic activity of the aqueous extract of $C$. crepidioides leaves in the treatment of hypertension as claimed by traditional healers and also to valorize the pharmacopeia and the flora Africa.

\section{Materials and Methods}

\section{Plant material}

C. crepidioides leaves were harvested from Bafoussam in the west region of Cameroon on June 30th 2017, and were identified at the National Herbarium of Cameroon (NHC) under registration number 20487/NHC.

\section{Animal material}

Wistar rats strain (130 - $180 \mathrm{~g})$ of two sexes, aged 2 to 3 months, originated from the Laboratory of Medicinal Plants, Health and Galenic Formulation of the Faculty of Sciences of the University of Ngaoundéré were used for this study. The living conditions of animals were in such a way that the environmental temperature was controlled at $25 \pm 1.5^{\circ} \mathrm{C}$, while the relative humidity was $45 \% \pm 10 \%$. Animals had a free access to water and food. All animals were subjected to a surgery under the supervision of a veterinary surgeon from the School of 
Veterinary Medicine, University of Ngaoundéré. Whereas the experimental procedure protocols were approved by the Institute of Animal Committee, the research was approved by the Animal Ethics Committee of the University of Ngaoundéré.

\section{Drugs}

Furosemide (2 $\mathrm{mg} / \mathrm{kg})$ and Amiloride Hydrochlorothiazide (AHCT) (14 $\mathrm{mg} / \mathrm{kg})$ were used as reference pharmacological substances.

\section{Preparation of the aqueous extract of the} leaves of $C$. crepidioides

Fresh leaves of $C$. crepidioides were washed and a sample of $1 \mathrm{~kg}$ was weighed and macerated in $1 \mathrm{~L}$ of water at room temperature for $12 \mathrm{hrs}$ before the filtration process using a Wattman paper $\mathrm{N}^{\circ} 3$. A total volume of $1.60 \mathrm{~L}$ of extract obtained was lyophilized at $-40^{\circ} \mathrm{C}$ to yield $26 \mathrm{~g}$ of powder that was stored at $20^{\circ} \mathrm{C}$.

\section{Phytochemical study}

Analytical tests for the identification of different group of metabolites in crude extracts of the leaves were made at the Institute of Medicinal Plants for Medicinal Research, Cameroon. The procedures described by Chen and $a l^{13}$ were used for the detection of various chemical groups. In view of the identification of the chemical structure of the compounds responsible for the diuretic activity, preliminary tests of the phytochemical study were conducted. Briefly, Essential oils from the aqueous extract of $C$. crepidioides were extracted with hexane. These extracts were then stitched onto plates of thin layer chromatography on silica, the first disclosure was obtained by ultraviolet radiation (254 $\mathrm{nm}$ and $365 \mathrm{~nm}$ ) and then with vanillin.

\section{Diuretic activity}

A preliminary screening was carried out to select "well urinated" rats. In the process, 1 $\mathrm{ml} / 100 \mathrm{~g}$ body weight of distilled water was orally administered to each rat. Treated rats were individually placed in metabolic cages, to undergo the collection of urine that was measured after every 6 hours. All animals that excreted more than $40 \%$ of the volume of distilled water administered were selected, while those that excreted less were excluded $^{14}$. After selection, 30 rats were divided into 6 groups of 5 rats, each of which was then individually placed in metabolic cages under acclimation for 7 days.

Furthermore, the aqueous extract of $C$. crepidioides leaves was administered to the rats at doses 75,100 and $125 \mathrm{mg} / \mathrm{kg}$ of body weight using an esophageal probe. Animals in the control group were treated with distilled water (negative control), Furosemide (2 mg / $\mathrm{kg}$ ) and Amiloride hydrochlorothiazide (14 $\mathrm{mg} / \mathrm{kg}$ ) (positive controls). All treated animals were individually placed in metabolic cages and submitted to a special urinary collection device. The urinary volume was determined at 0hr, 3hrs, 6hrs, 12hrs and 24hrs after administration of the single dose of the extract or reference drugs. All experimental procedures were approved by the institute of Ethical committee of Department of Biological Science of the University of Ngaoundéré 15/01/2015/UN/FS/DSB).

(ECDBSUN

\section{Parameters}

Treated animals were sacrificed by decapitation. Blood was collected in the heparinized EDTA tubes. The serum was separated by centrifugation at $3000 \mathrm{rpm}$ for 15 minutes and then stored at $-20^{\circ} \mathrm{C}$ for the determination of the biochemical parameters such as creatinine, urea, sodium ion, 
potassium ion, chloride ion, ALAT and ASAT.

The urinary concentrations of sodium and potassium ions were determined using the photometric flame (Jenway, PFP 7) as described by the standard method ${ }^{15}$. Creatinine (Creat), urea, and electrolyte concentrations in the serum and urine samples were evaluated using a bidirectional mass spectrophotometer. (Secomam RS 232C, France $)^{16}$. In animals treated with the extract and reference substances, urinary osmolarities and natriuresis were measured during the diuretic response, particularly when at the maximum excretion rate.

The osmolarity of plasma and urine samples was measured by cytometry using an osmometer (Knauer). Osmolar clearance (Cosm) was determined from plasma osmolality (POSM), urinary osmolarity (Uosm) and urine flow (V) according to the following formula: Cosm = Uosm. V/POSM. The GFR (glomerular filtration rate) was assessed by creatinine clearance (CreatC). The amount of $\mathrm{Na}^{+}$and $\mathrm{K}^{+}$was calculated as a parameter for the saluretic activity. The ratio of $\mathrm{Na}^{+} / \mathrm{K}^{+}$was calculated for the natriuretic activity. To estimate the carbonic anhydrase inhibition activity, the ratio of $\mathrm{Cl}^{-}$/ $\left(\mathrm{Na}^{+}+\mathrm{K}^{+}\right)$was calculated ${ }^{17}$.

\section{Measurement of Body Temperature}

The body temperature was measured using a digital thermometer. The sensor tip of the thermometer was introduced and held for 2 minutes in the anus of the animal. Animals with a body temperature between $35-38^{\circ} \mathrm{C}$ were selected while those with a temperature below or above this range were eliminated. This temperature was measured before and after $24 \mathrm{hrs}$ of administration of the aqueous extract.

\section{Statistical analysis}

Results were expressed as mean \pm standard deviation. The comparison of the averages was made using the ANOVA one-way test followed by the Krustal-Wallis test. The variance analysis software was Statgraphics Centurion XV. The difference was either not significant for $\mathrm{P}>0.05$, or significant for $\mathrm{P}<$ 0.05. Excel software was used in the plotting of graphs.

\section{Results and Discussion}

\section{Phytochemical study}

Phytochemical screening performed on crude extracts with methanol and ethyl acetate revealed the presence of several primary and secondary metabolites such as fatty acids, sugars and carotenoids, Athraquinones, glycosides, anthracene, saponins, alkaloids, tannins, Coumarins. Phenolic compounds including triterpenes, volatile oils and sterols are also present in the extract. The presence of flavonoids and alkaloids is remarkable. The result of the phytochemical studies is represented in Table 1. Four fractions were collected and analyzed to find out the presence of alkaloids, tannins, flavonoids, and Saponins. The fractions were eventually pooled into four and numbered $\mathrm{A}, \mathrm{B}, \mathrm{C}$, and $\mathrm{D}$ based on their predominant phytochemical reactions as shown in Table 1 . These initial observations and findings suggest that the aqueous extract of leaves of $C$. crepidioides contains several chemical compounds which have biological potential activity hence deserves further investigation.

Effect of the aqueous leaves extract of $C$. crepidioides on the effective doses on urinary volume

A single dose-response administration of the aqueous extract of $C$. crepidioides $(25,50,75$, 
100 and $125 \mathrm{mg} / \mathrm{kg}$ ) showed a significant increase $(\mathrm{P}<0.05)$ in the volume of urine 24 hours later. However, the urinary excretion was dose dependent (Figure 1). Screening of leaves extract doses showed a significant $(\mathrm{p}<$ 0.05 ) increase in the volume of urine excreted at $3 \mathrm{hrs}, 6 \mathrm{hrs}, 12 \mathrm{hrs}$ and $24 \mathrm{hrs}$ after administration. At the dose of $100 \mathrm{mg} / \mathrm{kg}$, the volume of urine increased by $106.1 \%$. The highest dose $(125 \mathrm{mg} / \mathrm{kg})$, induced $115.8 \%$ increase in the volume of urine of the treated group. Only $36.33 \%$ overload was eliminated in the negative control group, whereas HCTZ eliminated $76.65 \%$ and furosemide $87.87 \%$ of urine after $12 \mathrm{hrs}(\mathrm{P}<0.05)$ of administration. During the experiment, water consumption was significantly $(\mathrm{P}<0.05)$ increased in the rats subjected to plant extract treatment (from $22.8 \pm 2$ and $25.8 \pm 2.8$ $\mathrm{mL} /$ day), respectively for doses of 100 and $125 \mathrm{mg} . \mathrm{kg}$, and those treated with reference drugs $(14.2 \pm 4.6 \mathrm{~mL} /$ day for furosemide and $13 \pm 4.2 \mathrm{~mL} /$ day for amiloride) compared to distilled water treated rats.

Effect of the aqueous leaves extract of $C$. crepidioides on the lag time of urinary excretion

The lag time significantly decreased in animals treated with aqueous extract at 100 $\mathrm{mg} / \mathrm{kg}(42.5 \%), 125 \mathrm{mg} / \mathrm{kg}(50 \%)$, as well as in animals which were administrated with standard pharmacological drugs $(55 \%)$ compared to the control group (Figure 2). The overload eliminated after $1 \mathrm{hr}$ by rats treated with the three highest doses of $C$. crepidioides aqueous extract tested $(75,100$, and 125 $\mathrm{mg} / \mathrm{kg}$ ) were $110 \%$; $42.8 \%$ and $56.7 \% \%$ respectively whereas HCTZ eliminated $51.04 \%$ furosemide $61.87 \%$ and control 18.31 $\%(\mathrm{P}<0.05)$ (Figure 2$)$. The extract displayed a dose-dependent decrease as the first urination latency in $17.23 \mathrm{~min}(\mathrm{P}<0.05)$, $15.35 \mathrm{~min}(\mathrm{P}<0.01)$, and $13.22 \mathrm{~min}(\mathrm{P}<0.01)$ at doses 75, 100, and $125 \mathrm{mg} / \mathrm{kg}$. Negative control group average first urination latency was 45, $21 \mathrm{~min}$, furosemide $20.66 \mathrm{~min}$ $(\mathrm{P}<0.01)$, and HCTZ $22.45 \mathrm{~min}(\mathrm{P}<0.05)$ (Figure 1). All treatments induced at least a 3fold increase in the overload elimination compared with negative control group after 60 s. Only $30.54 \%$ overload was eliminated in the negative control group, whereas HCTZ eliminated $85.34 \%$ and furosemide $90.66 \%$ $(\mathrm{P}<0.05)$.

Effect of the aqueous leaves extract of $C$. crepidioides on cumulated urine volume excreted and pH

Figure 3 shows the changes on the cumulated volume of urine excreted and $\mathrm{pH}$ by rats $24 \mathrm{hrs}$ later, following treatment with various doses of $C$. crepidioides aqueous extract, administration of an equivalent volume of distilled water (negative controls), or treatment with one of the two diuretic drugs used as positive controls (furosemide, HCTZ). There was a significant increase $(\mathrm{p}<0.05)$ in the cumulated volume of urine excreted in $24 \mathrm{hrs}$ in animals treated with the plant extract (100.2\%, $106.12 \%$ and $115.82 \%$ respectively for 75,100 and $125 \mathrm{mg} / \mathrm{kg}$ ) compared to the negative control group. In rats administered with the reference pharmacological substances, a significant increase in urinary volume (122.04 \% and $50.97 \%$ respectively for furosemide and AHCT) was observed. The $\mathrm{pH}$ values $(6.6 \pm 0.1)$ of urine of rats treated with the extract of $C$. crepidioides were higher than the control group $6.2 \pm 0.2)$. However, the $\mathrm{pH}$ values $(6.7 \pm 0.1)$ of urine of animals treated with the extract were lower than that of rats treated with pharmacological substances $(7.0 \pm 0.1)$ (Figure 3$)$.

Effect of the aqueous leaves extract of $C$. crepidioides on the rectal temperature after 24hrs

It was noticed that, 24 hours after treatment, the initial and final rectal temperatures varied 
slightly and insignificantly $(\mathrm{p}>0.05)$. The difference between the initial and final temperatures at different doses compared to the control group (ED) showed no significant difference $(p>0.05)$ (Figure 4).

\section{Electrolyte excretion}

Effects of $C$. crepidioides on cumulative urinary excretion of sodium ions $\left(\mathrm{Na}^{+}\right)$

During the experiment, the significant increase in urinary volume $(\mathrm{p}<0.05)$ and urinary rate of sodium excretion was dose dependent $(387.56 \%, 423.56 \%$ and $482.46 \%$ respectively for 75,100 and $125 \mathrm{mg} / \mathrm{kg}$ per day compared to the control) (Figure 5). The Amiloride hydrochlorothiazide $(14 \mathrm{mg} / \mathrm{kg})$ induced a significant increase in sodium ions excretion $(90.23 \pm 3.11 \mathrm{mEq} / \mathrm{kg} / 24 \mathrm{~h})$ compared to the control group $(30.56 \pm 3.22$ $\mathrm{mEq} / \mathrm{kg} / 24 \mathrm{~h}$ ). Like Amiloride hydrochlorothiazide, Furosemide also induced a significant increase $(180.4 \pm 1.13$ $\mathrm{mEq} / \mathrm{kg} / 24 \mathrm{~h}$ ) compared to the control group $(30.56 \pm 3.22 \mathrm{mEq} / \mathrm{kg} / 24 \mathrm{~h})$.

Effects of $C$. crepidioides on cumulative urinary excretion of potassium ions $\left(\mathrm{K}^{+}\right)$

Figure 6 below indicates that the aqueous leave extract of $C$. crepidioides caused a significant increase $(\mathrm{p}<0.05)$ in urinary excretion of potassium ions after $24 \mathrm{hrs}$, of $13.43 \%, 99.41 \%$ and $139.56 \%$ respectively at the doses of 75, 100 and $125 \mathrm{mg} / \mathrm{kg}$ compared to the control group.

Urinary excretion of potassium ions increased from $17.23 \pm 2.68 \mathrm{mEq} / \mathrm{kg} / 24 \mathrm{~h}$ in control group to $25.33 \pm 3.33 \mathrm{mEq} / \mathrm{kg} / 24 \mathrm{~h}$ at dose $125 \mathrm{mg} / \mathrm{kg}$. whereas, animals treated with furosemide also showed a significant increase in urinary excretion of potassium ions $(37 \pm$ $1.21 \mathrm{mEq} / \mathrm{kg} / 24 \mathrm{~h})$ compared to the control group (17.23 $2.68 \mathrm{mEq} / \mathrm{kg} / 24 \mathrm{~h}$ ) (Figure 6).
Effects of $C$. crepidioides on cumulative urinary excretion of chloride $\left(\mathrm{Cl}^{-}\right)$

Aqueous extract of $C$. crepidioides showed a significant increase in the excretion of chloride ions. In figure 7 it was noticed that the urinary excretion of chloride ions increased significantly and proportionately to the concentrations of the extract of $233,33 \%$, $255.35 \%$ and $338.96 \%$ respectively at the doses of $(75,100$ and $125 \mathrm{mg} / \mathrm{kg})$ compared to the negative control group.

This significant increment reached a $443.03 \%$ rate in animals treated with furosemide and $192.6 \%$ in the group treated with the AHCT compared to negative control.

Excretion of chloride ions increased from $23.92 \pm 2.35 \mathrm{mEq} / \mathrm{kg} / 24 \mathrm{~h}$ in negative control to $104.99 \pm 3.5 \mathrm{mEq} / \mathrm{kg} / 24 \mathrm{~h}$ at the dose of $125 \mathrm{mg} / \mathrm{kg}$ (Figure 7).

Effect of the aqueous leaves extract of $C$. crepidioides on the natriuretic, saluretic and CAI activities in urine

During the experiment, the natriuretic activity $(\mathrm{Na}+/ \mathrm{K}+)(\mathrm{p}<0.05)$ in rats treated with aqueous extract at $75 \mathrm{mg} / \mathrm{kg} \quad(156.06 \%)$, $100 \mathrm{mg} / \mathrm{kg} \quad(221.33 \%)$ and $125 \mathrm{mg} / \mathrm{kg}$ $(187.86 \%)$ showed a significant increase compared to the negative control group (distilled water). In animals treated with furosemide and amiloride, there was a significant increase $(\mathrm{p}<0.05)$ in natriuretic activity from $94.14 \%$ to $143.09 \%$ compared to control group.

As far as the saluretic activity is concerned, the increment was significant $(\mathrm{p}<0.05)$ from $332.17 \%$, to $352.1 \%$ and $395.6 \%$ with equivalent doses of $75,100,125 \mathrm{mg} / \mathrm{kg}$ respectively compared to animals group treated with distilled water. In positive control group (animals treated furosemide and 
AHCT), the saluretic activity was also significantly increased from $450.7 \%$ to $110.35 \%$ for furosemide and amiloride compared to control group (distilled water).

The aqueous leaves extract at doses of 75, 100 and $125 \mathrm{mg} / \mathrm{kg}$ resulted in a significant decrease $(\mathrm{p}<0.05)$ in the CAI activity by $35.5 \%, \quad 35.5 \%$ and $28 \%$ respectively, compared to the control group (distilled water). The administration of furosemide $(7 \%)$ and amiloride $(5.17 \%)$ indicated a significant decrease $(\mathrm{p}<0.05)$ in CAI activity in treated animals compared to the untreated group.

The natriuretic and saluretic index was significantly $(\mathrm{p}<0.05)$ elevated in the rats treated with the aqueous leaves extract and in rats treated with reference drugs compared to animals treated with distilled water (index $=$ 1.00). On the other hand, there was no significant decrease $(p>0.05)$ in CAI index within animals treated with the aqueous leaves extract and the reference pharmacological substances compared to the control group (CAI index $=1)$ (Table 2$)$.

Effect of the aqueous leaves extract of $C$. crepidioides on the kidneys functioning index

Table 3 below shows the effect of the aqueous leaves extract of $C$. crepidioides on the kidneys functioning index. The significant increase in creatinine in urine of animals treated with furosemide was $180.80 \%$, and $112.6 \%$ in those animals treated with amiloride compared to that of the control group. Similarly, the doses of 100 and 125 $\mathrm{mg} / \mathrm{kg}$ indicated a significant increase of $22.22 \%$ and $204.7 \%$ respectively compared to the negative control.

Creatinine clearance significantly decreased $(\mathrm{p}<0.05)$ and was dose-dependent at $75 \mathrm{mg} /$ $\mathrm{kg} \quad(28.02 \%), \quad 100 \mathrm{mg} / \mathrm{kg} \quad(200 \%) \quad$ and $125 \mathrm{mg} . \mathrm{kg}(542.8 \%)$ compared to the control group. This was also observed in animals treated with furosemide and amiloride, which have a creatinine clearance of $0.021 \pm 0.02$ and $0.018 \pm 0.019 \mathrm{~mL} / \mathrm{min}$ respectively, compared to $0.9 \pm 0.01 \mathrm{~mL} / \mathrm{min}$ in animal treated only with distilled water as the control.

The glomerular filtration rate (GFR) significantly decreased $(\mathrm{p}<0.05)$ by $148.4 \%$ for furosemide and $238 \%$ for AHCT compared to control. The aqueous extract of C. crepidioides caused a significant decrease ( $\mathrm{p}<0.05$ ) of the glomerular filtration rate by $91.56 \%$ at $75 \mathrm{mg} / \mathrm{kg}, 341.6 \%$ at $100 \mathrm{mg} / \mathrm{kg}$ and $783.3 \%$ at $125 \mathrm{mg} / \mathrm{kg}$, and was dosedependent compared to the control group.

The amount of filtrated urea increased significantly $(\mathrm{p}<0.05)$ in furosemide-treated animals $(33.08 \%)$ and in those administrated with AHCT (30.8\%) compared to animals treated with distilled water. In the same vein, the plant extract at $125 \mathrm{~m} / \mathrm{kg}$ resulted in a significant $(\mathrm{p}<0.05)$ increase in the amount of filtrated urea (17.58\%) compared with distilled water treated animals.

The Uosm decreased significantly compared to the control rats $(\mathrm{P}<0.05)$, with percentages of $79.08 \%, 72.81 \%$, and $56.35 \%$ respectively for extract of $C$. crepidioides doses of 75, 100 and $125 \mathrm{mg} / \mathrm{kg}, 15.20 \%$ for furosemide and $24.68 \%$ for AHCT.

Furosemide and AHCT significantly increased $(\mathrm{P}<0.05)$ Cosm by $43.46 \%$ and $60.87 \%$ respectively compared to the control group. Cosm of rats treated with $C$. crepidioides doses of 75 and $100 \mathrm{mg} / \mathrm{kg}$ decreased significantly $(\mathrm{P}<0.05)$ by $6.91 \%$ and $2.23 \%$ respectively compared to control group. The dose of $125 \mathrm{mg} / \mathrm{kg}$ did not show any significant increase in Cosm. $\mathrm{C}_{\mathrm{H} 2 \mathrm{O}}$ 
significantly increased by $16.35 \%, 19.98 \%$ and $23.63 \%$ respectively at the highest dose of extract $(125 \mathrm{mg} / \mathrm{kg}), \quad$ AHCT and furosemide (Table 3 ).

Effect of the aqueous extract of the leaves of C. crepidioides on biochemical parameters of blood

Several biochemical parameters were evaluated in the blood of rats treated with aqueous leaves extract of $C$. crepidioides, reference pharmacological substances (furosemide and AHCT) and in animals treated with distilled water (Table 4). The concentrations of $\mathrm{Na}+, \mathrm{K}+$ and $\mathrm{Cl}$ - ions increased significantly $(\mathrm{p}<0.05)$ at all aqueous leaves extract doses.

The animals treated with the furosemide and AHCT equally show a significant increase ( $P$ $<0.05)$ in creatinine and urea levels $(\mathrm{P}<$ $0.05)(28.57 \%$ and $4 \%$ for the furosemide; $25.39 \%$ and $12 \%$ for the AHCT) compared to the control test.
There was a significant increase in the rate of urea in the blood from $41 \%, 42.8 \%$ and $43 \%$ respectively for the doses of 75,100 and 125 $\mathrm{mg} / \mathrm{kg}$ compared to the control test. In contrast, no significant change in the rate of creatinine was observed in the animals that where treated with an aqueous extract.

Effect of the aqueous leaves extract of Crassocephalum crepidioides on transaminase levels in blood and urine

Table 5 below shows the effect of the aqueous leaves extract of $C$. crepidioides on the amount of ALAT and ASAT in the blood and in urine. The aqueous extract at all doses resulted in a significant decrease $(\mathrm{p}<0.05)$ of serum transaminase levels $(317.02 \%$, $318.07 \%$ and $320.12 \%$ for ALAT and $146.22 \%, 150.12 \%$ and $150.1 \%$ ) for ASAT, respectively at doses 75,100 and $125 \mathrm{mg} / \mathrm{kg}$ ) compared to the control animals. In urine, no significant difference was observed in the level of transaminase between the aqueous extract treated-rats and the distilled water treated-rats.

Table.1 Phytochemical screening Result, quantitative analysis and reactions of the four fractions

\begin{tabular}{|l|l|l|l|l|l|l|}
\hline & \multicolumn{5}{|c|}{ Fractions } \\
\hline Phytochemicals & Indication of leaves extract & Content $(\%)$ & A & B & C & D \\
\hline Anthocyanin & + & $0.693 \pm 0.012$ & - & - & - & - \\
\hline Glycoside & + & $0.312 \pm 0.025$ & - & - & - & - \\
\hline Flavonoid & +++ & $16.210 \pm 0.162$ & +++ & - & - & - \\
\hline Alkaloid & ++ & $11.530 \pm 0.187$ & - & ++ & - & - \\
\hline Phenol & ++ & $0.457 \pm 0.035$ & - & - & - & - \\
\hline Steroids & ++ & $0.374 \pm 0.033$ & - & - & - & - \\
\hline Tannins & + & $0.268 \pm 0.048$ & - & - & - & ++ \\
\hline Saponins & ++ & $5.345 \pm 0.057$ & - & - & ++ & - \\
\hline
\end{tabular}

+++ , presence of bioactive compound in very high concentrations;

++ , presence of bioactive compound in high concentrations;

+ , presence of bioactive;

- , absence of bioactive compound 
Table.2 Natriuretic, saluretic and CAI activities in the urine

\begin{tabular}{|l|c|c|c|c|c|c|c|}
\hline & $\begin{array}{c}\text { Doses } \\
(\mathrm{mg} / \\
\mathrm{kg})\end{array}$ & $\begin{array}{c}\text { Natriuretic } \\
\text { activity (Na } \\
+/ \mathrm{K}+)\end{array}$ & $\begin{array}{c}\text { Saluretic } \\
\text { activity }\left(\mathrm{Na}^{+}+\right. \\
\left.\mathrm{Cl}^{-}\right)\end{array}$ & $\begin{array}{c}\text { CAI activitic } \\
(\mathrm{Cl}-/(\mathrm{Na}+\mathrm{K}+))\end{array}$ & $\begin{array}{c}\text { Natriuretic } \\
\text { index }\end{array}$ & $\begin{array}{c}\text { Saluretic } \\
\text { index }\end{array}$ & $\begin{array}{c}\text { CAI } \\
\text { index }\end{array}$ \\
\hline control & $\mathrm{ED}$ & $2,39 \pm 0,1$ & $57,28 \pm 1,76$ & $0,61 \pm 0,63$ & 1.00 & 1.00 & 1.00 \\
\hline & 75 & $6,12 \pm 6,92^{*}$ & $247,55 \pm 1,5^{*}$ & $0,45 \pm 0,58^{*}$ & $2.56^{*}$ & $4,32^{*}$ & 0,73 \\
\hline extract & 100 & $7,68 \pm 0,50^{*}$ & $258,97 \pm 0,51^{*}$ & $0,45 \pm 1,21^{*}$ & $3.21^{*}$ & $4,52^{*}$ & 0,73 \\
\hline & 125 & $6,88 \pm 11^{*}$ & $283,57 \pm 3,04^{*}$ & $0,48 \pm 1,03^{*}$ & $2.87^{*}$ & $4,95^{*}$ & 0,78 \\
\hline FURO & 5 & $4,64 \pm 0,78^{*}$ & $315,48 \pm 3,98^{*}$ & $0,57 \pm 0,19^{*}$ & $1.94^{*}$ & $5,5^{*}$ & 0,93 \\
\hline AHCT & 14 & $5,81 \pm 0,43^{*}$ & $167,63 \pm 2,63^{*}$ & $0,58 \pm 0,35^{*}$ & $2.43^{*}$ & $2,92^{*}$ & 0,95 \\
\hline
\end{tabular}

Each value represents the mean $\pm \mathrm{SEM}, \mathrm{n}=5$. $(* \mathrm{P}<0.05)$ significant difference compared to the control group $(\mathrm{ED}=$ Distilled Water). FURO = Furosemide, AHCT $=$ Amiloride Hydrochlorothiazide, CAI $=$ Inhibition of Carbonic Anhydrase

Table.3 Effect of the aqueous leaves extract of $C$. crepidioides on the kidneys functioning index

\begin{tabular}{|l|l|l|l|l|l|l|}
\hline Dose $(\mathrm{mg} / \mathrm{kg})$ & \multicolumn{1}{|c|}{ control } & \multicolumn{1}{c|}{75} & \multicolumn{1}{c|}{100} & \multicolumn{1}{c|}{125} & \multicolumn{1}{c|}{ Furosemide } & \multicolumn{1}{c|}{ AHCT } \\
\hline Creatinine $(\mathrm{mg} / \mathrm{dl})$ & $0,63 \pm 0,31$ & $0,32 \pm 0,04$ & $0,77 \pm 0,38^{*}$ & $1,92 \pm 0,35^{*}$ & $1,77 \pm 0,05^{*}$ & $1,34 \pm 0,05^{*}$ \\
\hline Creat C $(\mathrm{ml} / \mathrm{min})$ & $0,9 \pm 0,01$ & $0,703 \pm 0,75^{*}$ & $0,30 \pm 0,13^{*}$ & $0,14 \pm 0,11^{*}$ & $0,021 \pm 0,02^{*}$ & $0,018 \pm 0,019^{*}$ \\
\hline GFR $(\mathrm{ml} / \mathrm{min})$ & $1,59 \pm 0.41$ & $0,83 \pm 0,90^{*}$ & $0,36 \pm 0,16^{*}$ & $0,18 \pm 0,14^{*}$ & $0,64 \pm 0,07^{*}$ & $0,47 \pm 0,07^{*}$ \\
\hline Urea $(\mathrm{mg} / \mathrm{dl})$ & $17,12 \pm 2,33$ & $14,42 \pm 9,05$ & $18,24 \pm 4,87$ & $20,13 \pm 5,59^{*}$ & $22,81 \pm 1.7^{*}$ & $22.4 \pm 1.3^{*}$ \\
\hline Uosm $(\mathrm{mOsmol} / \mathrm{kg})$ & $197 \pm 9$ & $110 \pm 11^{*}$ & $114 \pm 15^{*}$ & $126 \pm 12^{*}$ & $171 \pm 12^{*}$ & $158 \pm 16^{*}$ \\
\hline $\mathrm{Cosm}(\mathrm{mL} / \mathrm{min})$ & $0.046 \pm 0.005$ & $0.043 \pm 0.012^{*}$ & $0.045 \pm 0.012^{*}$ & $0.048 \pm 0.017$ & $0.074 \pm 0.021^{*}$ & $0.066 \pm 0.011^{*}$ \\
\hline $\mathrm{CH}_{2} \mathrm{O}(\mathrm{mL} / \mathrm{min})$ & $0.055 \pm 0.011$ & $0.054 \pm 0.012$ & $0.056 \pm 0.018$ & $0.064 \pm 0.016^{*}$ & $0.068 \pm 0.011^{*}$ & $0.066 \pm 0.013^{*}$ \\
\hline
\end{tabular}

Each value represents the mean $\pm \mathrm{ESM}, \mathrm{n}=5$. $* \mathrm{P}<0.05$ significant difference compared to control $(\mathrm{ED}=$ Distilled Water). $\mathrm{Cl}$ Crea $=$ Creatinine Clearance, $\mathrm{DFG}=$ Glomerular Filtration Rate, $\mathrm{AHCT}=$ Amiloride Hydrochlorothiazide, $\mathrm{mEq}=$ milliequivalent

Table.4 Effect of the aqueous extract of the leaves of Crassocephalum crepidioides on biochemical parameters of blood

\begin{tabular}{|c|c|c|c|c|c|c|c|}
\hline & $\begin{array}{c}\text { Doses } \\
(\mathrm{mg} / \mathrm{kg})\end{array}$ & $\begin{array}{c}\text { creatinine } \\
(\mathrm{mg} . \mathrm{dl})\end{array}$ & urea $(\mathrm{mg} . \mathrm{dl})$ & $\mathrm{Na}+(\mathrm{mEq} / \mathrm{L})$ & $\mathrm{K}+(\mathrm{mEq} / \mathrm{L})$ & $\mathrm{Cl}-(\mathrm{mEq} / \mathrm{L})$ & $\begin{array}{c}\text { Posm } \\
(\mathrm{mOsmol} / \mathrm{kg})\end{array}$ \\
\hline control & ED & $0,63 \pm 0,31$ & $2,5 \pm 0,14$ & $22,39 \pm 2,72$ & $5,02 \pm 0,51$ & $13,85 \pm 1,61$ & $252.12 \pm 21.21$ \\
\hline & 75 & $0,92 \pm 0,3$ & $2,91 \pm 0,73^{*}$ & $60,17 \pm 0,40^{*}$ & $17,46 \pm 0,53^{*}$ & $78,72 \pm 0,82^{*}$ & $257.23 \pm 2.23^{*}$ \\
\hline extract & 100 & $0,64 \pm 0,27$ & $2,93 \pm 1,02^{*}$ & $59,5 \pm 0,63^{*}$ & $18,59 \pm 0,55^{*}$ & $65,68 \pm 1,52^{*}$ & $262.43 \pm 31.43^{*}$ \\
\hline & 125 & $0,58 \pm 0,028$ & $3,57 \pm 1,03^{*}$ & $54,62 \pm 0,84^{*}$ & $17,72 \pm 0,75^{*}$ & $68,88 \pm 1,52^{*}$ & $267.62 \pm 42.67 *$ \\
\hline FURO & 5 & $0,81 \pm 0,25^{*}$ & $2,6 \pm 0,14^{*}$ & $39,95 \pm 1,6^{*}$ & $9,94 \pm 1,39 *$ & $15,09 \pm 0,51^{*}$ & $268.82 \pm 32.84 *$ \\
\hline AHCT & 14 & $0,79 \pm 0,08^{*}$ & $2,8 \pm 0,14^{*}$ & $29,23 \pm 2,33^{*}$ & $7,84 \pm 0,39^{*}$ & $10,59 \pm 0,83^{*}$ & $267.35 \pm 44.57^{*}$ \\
\hline
\end{tabular}

Each value represents the mean $\pm \mathrm{ESM}, \mathrm{n}=5$. $* \mathrm{P}<0.05$ significant difference compared to control $(\mathrm{ED}=$ Distilled Water), $\mathrm{AHCT}=$ Amiloride Hydrochlorothiazide, $\mathrm{mEq}=$ milliequivalent 
Table.5 Effect of the aqueous leaves extract of $C$. crepidioides on the amount of ASAT and ALAT in the blood and in urine

\begin{tabular}{|l|c|c|c|c|c|}
\hline \multirow{2}{*}{ urine } & & Control & & Extract $(\mathrm{mg} / \mathrm{kg})$ & \\
\cline { 3 - 6 } & & ED & 75 & 100 & 125 \\
\hline \multirow{2}{*}{ Blood } & ASAT & $46,66 \pm 0,82$ & $44,744 \pm 1,1$ & $42,733 \pm 0,34$ & $40,644 \pm 1,72$ \\
\cline { 2 - 6 } & ALAT & $59,74 \pm 1,71$ & $48,016 \pm 0,15$ & $48,595 \pm 0,24$ & $46,732 \pm 1,8$ \\
\cline { 2 - 6 } & ASAT & $92,20 \pm 3,72$ & $37,445 \pm 0,04^{*}$ & $36,859 \pm 1,17 *$ & $36,853 \pm 1,84^{*}$ \\
\cline { 2 - 6 } & ALAT & $183,20 \pm 3,72$ & $43,930,9 *$ & $43,748 \pm 0,53^{*}$ & $43,606 \pm 1,67 *$ \\
\hline
\end{tabular}

Each value represents the mean \pm ESM. $* \mathrm{P}<0.05$ significant difference compared to control $(\mathrm{ED}=\mathrm{Distilled}$ Water $).$ ALAT $=$ Alanine Aminotransferase, ASAT $=$ Aspartate Aminotransferase

Table.6 Effect of the aqueous leaves extract of $C$. crepidioides on the urine output index and electrolytic excretion index in 24 hours of urine collection

\begin{tabular}{|c|c|c|c|c|c|}
\hline Drugs $(\mathrm{mg} / \mathrm{kg})$ & Diuretic index & $\mathrm{Na}^{+}$index & $\mathrm{Cl}^{-}$index & $\begin{array}{c}\mathrm{K}^{+} \\
\text {index }\end{array}$ & $\mathrm{n}$ \\
\hline Control & 1.00 & 1.00 & 1.00 & 1.00 & 5 \\
\hline 75 & 2.002 & 5.29 & 3.22 & 1.74 & 5 \\
\hline Extract & 2.06 & 5.58 & 3.32 & 1.74 & 5 \\
\hline 125 & 2.15 & 6.01 & 3.83 & 2.07 & 5 \\
\hline \multirow{2}{*}{$\begin{array}{l}\text { Furosémide }(5 \mathrm{mg} / \mathrm{kg}) \\
\text { HCTZ }\end{array}$} & 2.22 & 6.07 & 4.88 & 3.13 & 5 \\
\hline & 1.50 & 3.25 & 2.56 & 1.34 & 5 \\
\hline
\end{tabular}

$\mathrm{n}$ is the number of animals used in each group; diuretic index: urine volume of test group/urine volume of control group. $\mathrm{Na}^{+}$index, sodium excretion in test group/sodium excretion in control group. $\mathrm{K}^{+}$index, potassium excretion in test group/potassium excretion in control group. $\mathrm{Cl}^{-}$index, chloride excretion in test group/chloride excretion in control group

Fig.1 Effect of the aqueous leaves extract of $C$. crepidioides on the urinary volume

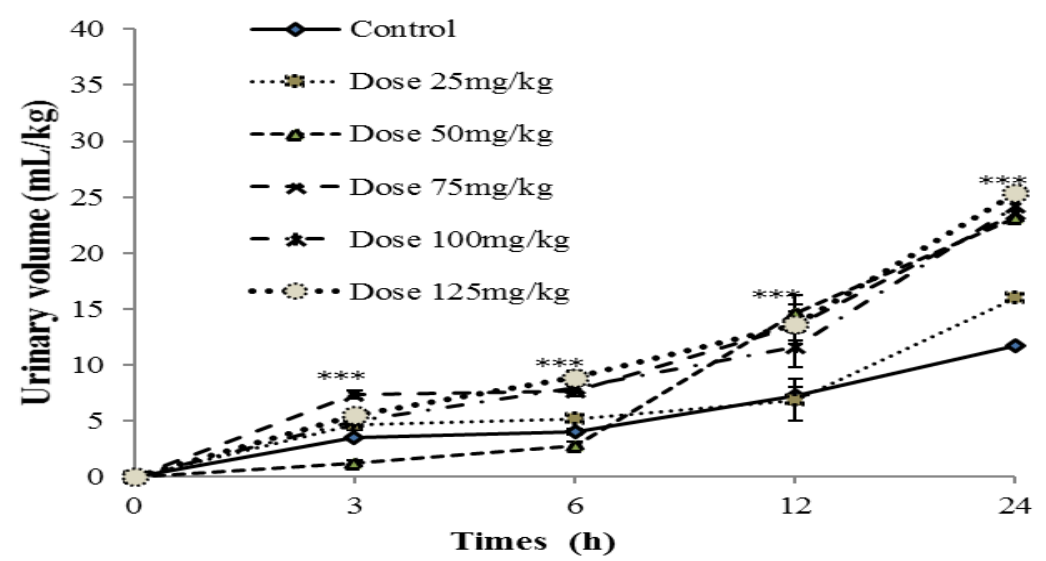

Values are means \pm S.E.M., $\mathrm{n}=5$, * significant difference compared to the control 
Fig.2 Overload eliminated and urination latency

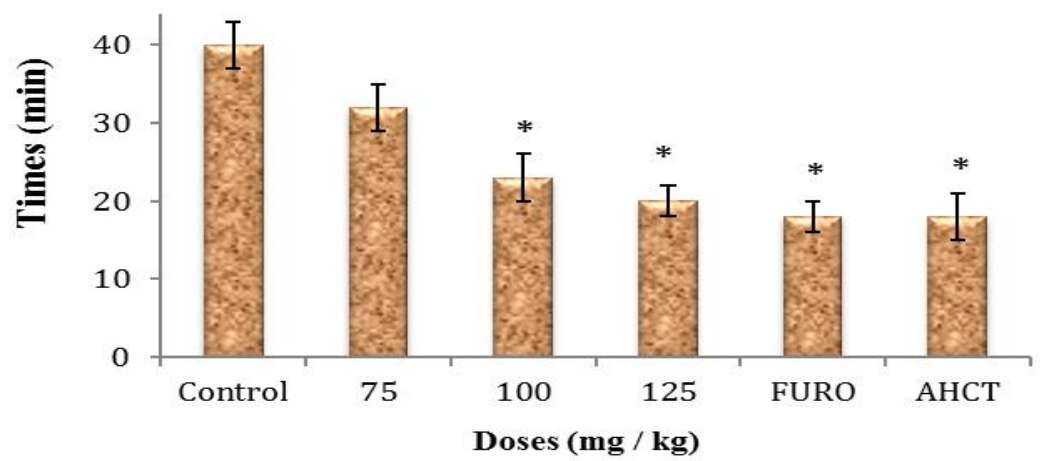

Each bar represents the mean \pm ESM. AHCT $=$ Amiloride Hydrochlorothiazide. $\mathrm{FURO}=$ Furosemide

Fig.3 pH and the cumulated urinary excretion volume at different time intervals

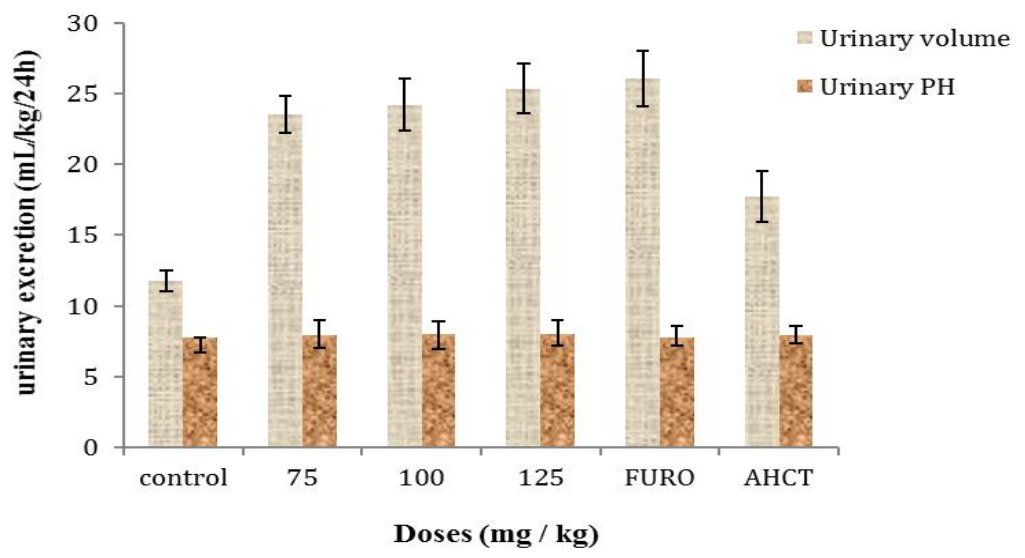

Each bar represents the mean $\pm \mathrm{SEM}, \mathrm{n}=5, \mathrm{AHCT} .=$ Amiloride Hydrochlorothiazide; FURO $=$ Furosemide. $* \mathrm{P}<$ 0,05 significant difference compared to control (Distilled Water)

Fig.4 Rectal temperature after 24 hours. Each bar represents the mean \pm SEM, $n=5$. AHCT $=$ Amiloride Hydrochlorothiazide, FURO = Furosemide

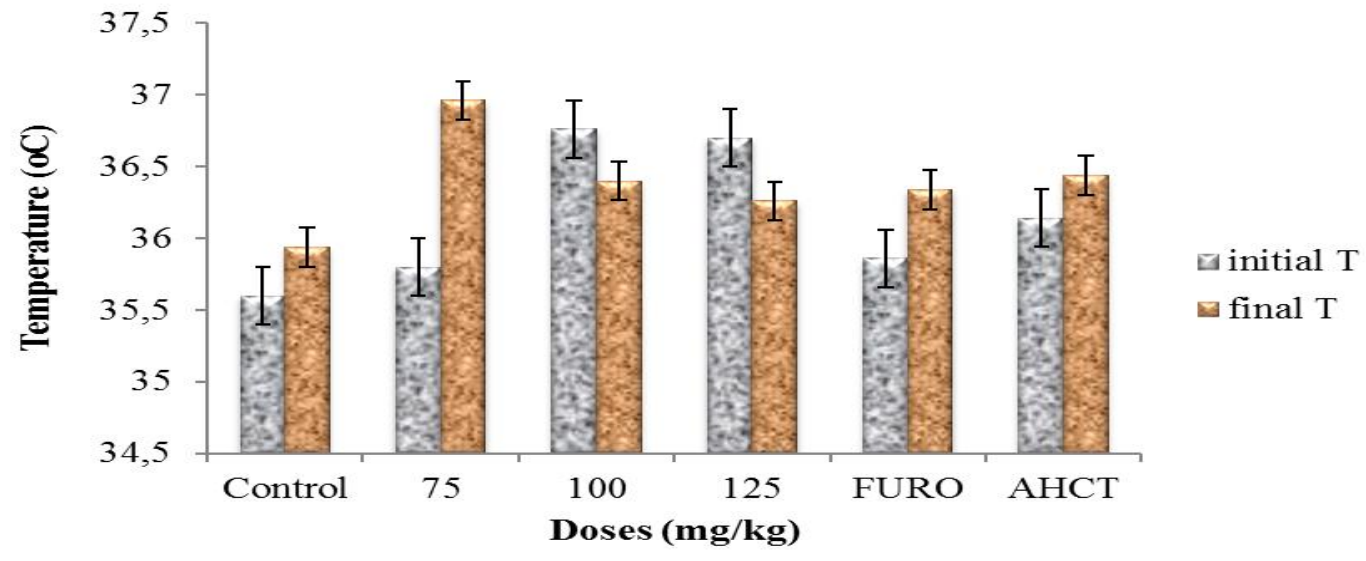


Fig.5 Effect of $C$. crepidioides on cumulative urinary excretion volume of $\mathrm{Na}+$ at different time intervals.

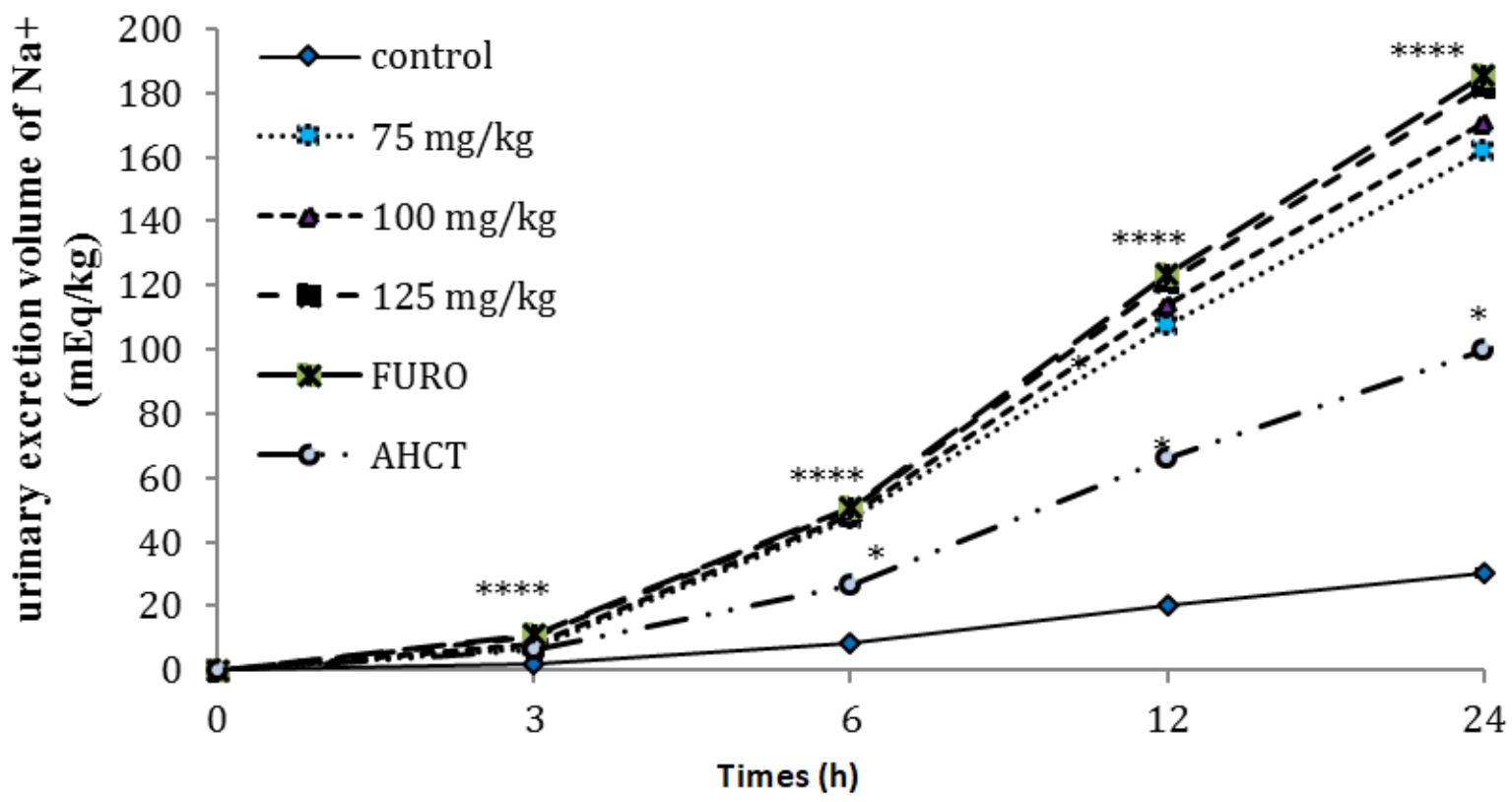

Each curve represents the mean \pm S.E.M., $\mathrm{n}=5$, AHCT $=$ Amiloride Hydrochlorothiazide;

FURO $=$ Furosemide. $(* \mathrm{P}<0.05)$ significant difference from the control

Fig.6 Effect of the aqueous leaves extract of $C$. crepidioides on the urinary excretion of $\mathrm{K}+\mathrm{at}$ different time intervals.

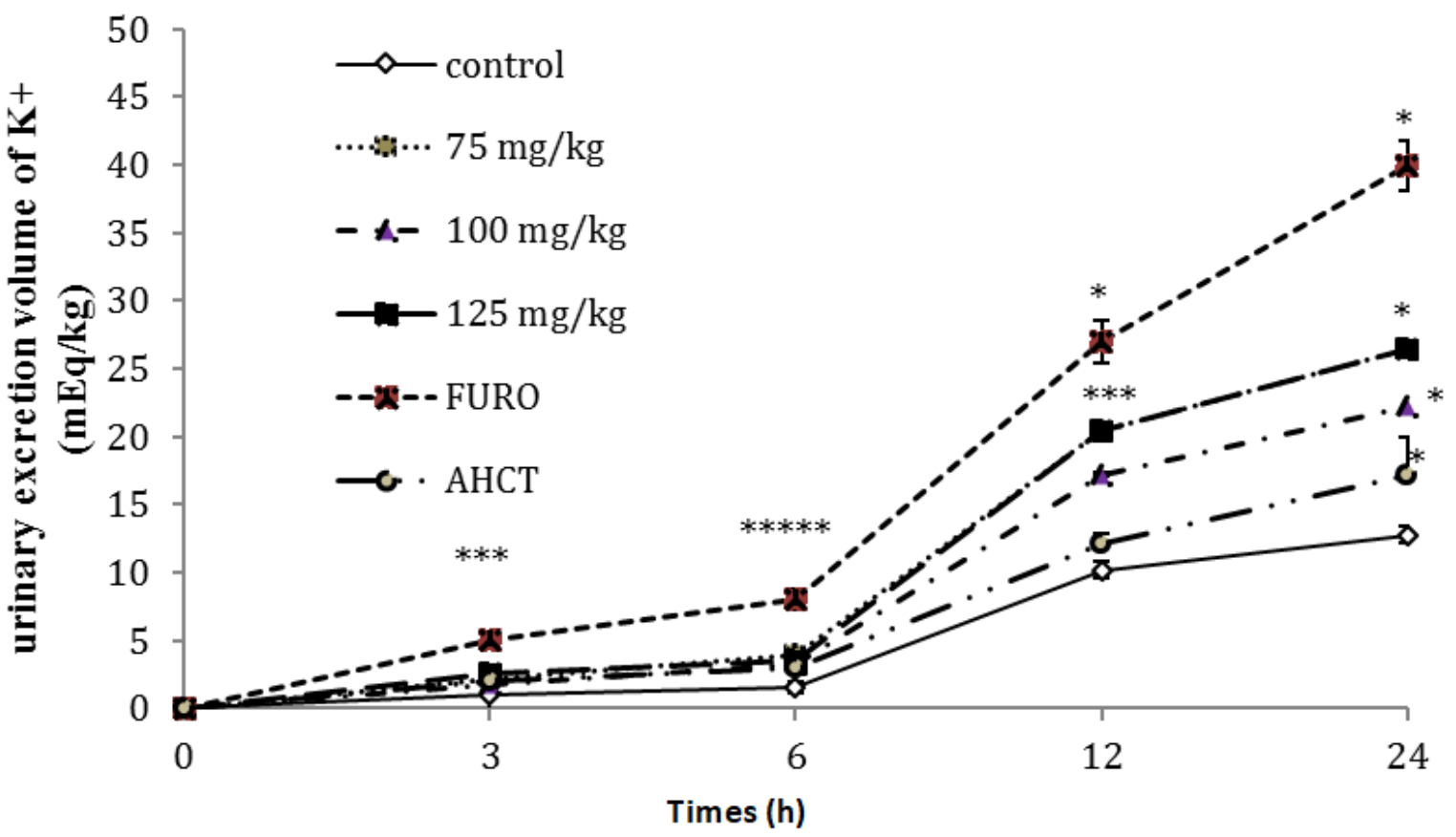

Each curve represents the mean $\pm \mathrm{SEM}, \mathrm{n}=5$, AHCT $=$ Amiloride Hydrochlorothiazide; FURO $=$ Furosemide. $(* \mathrm{p}<0,05)$ significant difference from the control 
Fig.7 Effect of the aqueous leaves extract of $C$. crepidioides on the urinary excretion of Chloride ions at different time intervals.

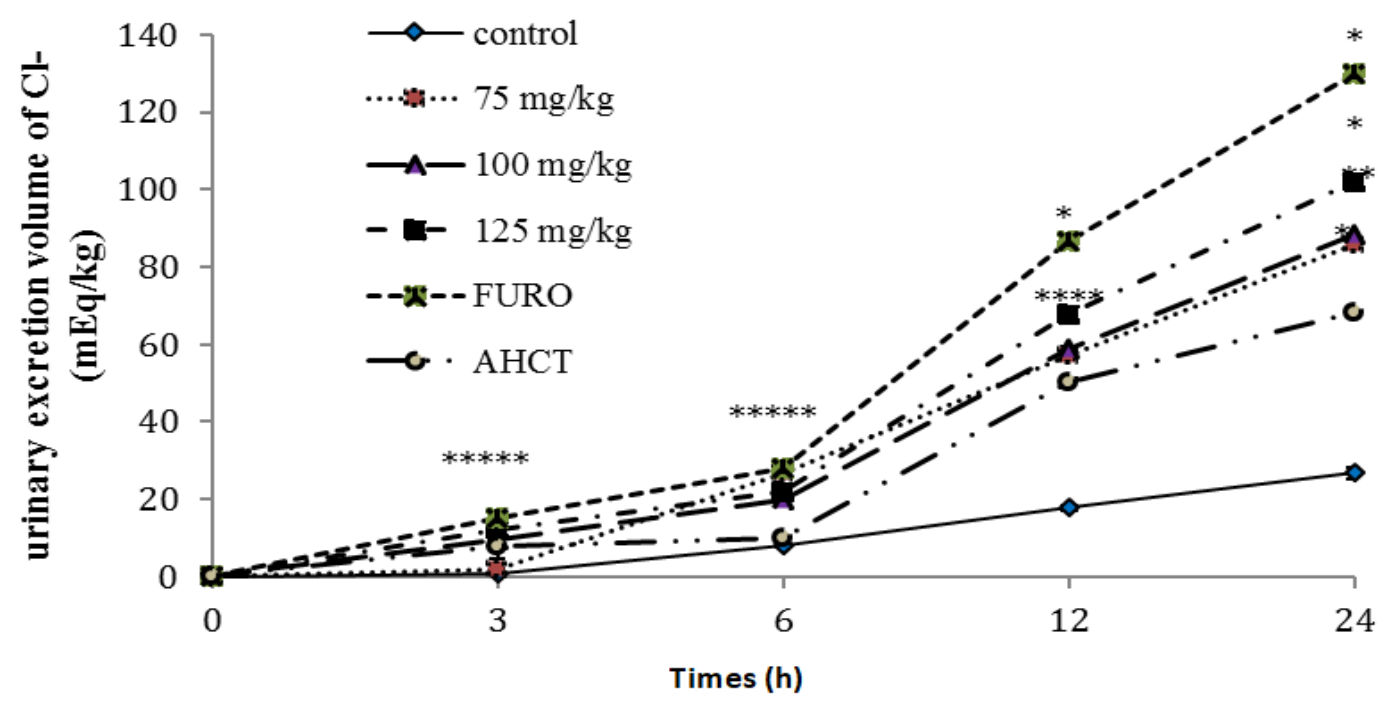

Each curve represents the mean $\pm \mathrm{SEM}, \mathrm{n}=5$, AHCT $=$ Amiloride Hydrochlorothiazide; FURO $=$ Furosemide $(* p<0,05)$ significant difference compared to the control

Effect of the aqueous leaves extract of $C$. crepidioides on the urine output index and electrolytic excretion index in 24 hours of urine collection

Diuretic index of the aqueous extract of $C$. crepidioides at doses of 100 and $125 \mathrm{mg} / \mathrm{kg}$ is lower than that of furosemide and higher than that of HCTZ (Table 6). The diuretic index passed from 1 in the control to 2.15 in rats treated with the dose of $125 \mathrm{mg} / \mathrm{kg}$. The index of $\mathrm{Na}^{+}, \mathrm{Cl}^{-}$and $\mathrm{K}^{+}$increased with the dose of $125 \mathrm{mg} / \mathrm{kg}$ compared to the control group (Table 6).

The increase in water consumption observed during the experiment could be attributed to the diuretic power of the plant extract, which causes excessive excretion of urine, and consequently, an increase in water intake by animals. The urinary $\mathrm{pH}$ of 6.5 and 8 could be a proof that this plant consumed as vegetable could contribute to the diuretic effect that maintains the acid-base balance, bearing in mind that alkaline foods are generally fruits and vegetables ${ }^{18}$. The body temperature of animals did not change during handling, reflecting the fact that $C$. crepidioides has no antipyretic activity. A similar result was obtained by Ntchapda et al., ${ }^{19}$, who showed that the aqueous root bark extract of Zanthoxylum heitzii has no antipyretic activity in rats. The significant increase in urinary volume at all time frames for doses 75, 100 and $125 \mathrm{mg} / \mathrm{kg}$ during animal screening indicated that these were the effective doses of the drug.

Whereas the increase in urinary volume after 3 hours of administration of extracts reveals the immediate effect of the plant extract, the one after 24 hours $(100.2 \%, 106.1 \%$ and $115.82 \%$ corresponding to 75,100 and $125 \mathrm{mg} . \mathrm{kg}$, and 124.3 and $51 \%$ for the Furosemide and Amiloride compared to the negative control are indications that the aqueous extract of $C$. crepidioides is quite diuretic. It speeds up and increases the elimination of the overloaded fluids. This increase in diuresis may be attributed to the presence of flavonoids and saponosides in the extract as claimed by Magharani and $a .^{20}$. 
These results are in agreement with those of Ntchapda and $a .^{21}$, who had achieved an $82.52 \%$ increase in urinary excretion for $375 \mathrm{mg} / \mathrm{kg}$ of aqueous extract of Fucus glusoma. It is also possible that the aqueous extract of $C$. crepidioides might have caused a cumulative effect of several active substances due to active secondary metabolites synthesis $^{21}$. Furthermore, the increase in urinary excretion could be attributed to the direct effect of the transport of an active component, or the indirect modification of the oncotic and hydrostatic pressure within the peritubular capillaries $^{22,23}$.

In addition to the elimination of urine, there was a significant excretion $(\mathrm{p}<0.05)$ of $\mathrm{Na}+$ and $\mathrm{K}+$ ions compared to distilled water treated animals. It was noted that the aqueous leaves extract of $C$. crepidioides at dose 125 $\mathrm{mg} / \mathrm{kg}$ qualitatively increased the urine electrolyte excretion ( $\mathrm{Na}+, \mathrm{K}+$ and $\mathrm{Cl}-)$, similar to furosemide which is known for its potential saluretic and diuretic effects.

The elimination of $\mathrm{Na}^{+}$by furosemide and the different aqueous leaves extract doses of $C$. crepidioides could be explained by the fact that these substances act on the various segments of the nephron ${ }^{24}$. It is therefore possible that the aqueous extract of $C$. crepidioides acts in a similar way as furosemide on the $\mathrm{Na}^{+}, \mathrm{K}^{+}, \mathrm{Cl}^{-}$co-transporters located on the ascending branch of Henle's loop of the nephron thus inhibiting the direct reabsorption of $\mathrm{Na}^{+}, \mathrm{K}^{+}, \mathrm{Cl}^{-}$through competition with the $\mathrm{Cl}^{-}$site of the Cotransporter. This will end up allowing an excretion of $20-25 \%$ of the amount of filtered $\mathrm{Na}^{+25}$. The presence of the sodium pump between the tubular cells and the interstitial fluid prevents sodium from migrating to the tubular cell ${ }^{26}$. Urinary excretions of sodium and to a lesser extent potassium suggest that the extract inhibits the sodium pump located on the ascending branch of the Henle's loop ${ }^{27}$.
The increase in $\mathrm{Na}^{+}$excretion could also be the result of the inhibitory effect of our aqueous extract. The aqueous extract of $C$. crepidioides might have acted by inhibiting the angiotensin-converting enzyme, leading to a decrease in the secretion of aldosterone, thus promoting an increase in the urinary excretion of sodium ${ }^{28}$. In addition, increased sodium excretion had been shown to decrease the rate of glomerular filtration by increasing the $\mathrm{Na}^{+}$loading required for $\mathrm{Na}^{+} / \mathrm{K}^{+}$ exchanges, or by stimulating these exchanges via the hyperaldosteronism it causes, and thus, reducing the blood mass ${ }^{14}$. The increase in natriuresis in response to acute treatment with the aqueous leaves of $C$. crepidioides partly explains the increase in diuresis ${ }^{29,30}$.

The results of this study indicated a significant $(p<0.05)$ increase in natriuretic activity at all extract doses, as well as the reference drugs compared to the negative control group. Studies by Ntchapda and al. ${ }^{17}$ pointed out that when the ratio $\mathrm{Na}^{+} / \mathrm{K}^{+}>2$, the extract had a significant natriuretic activity, causing a higher urinary excretion of sodium than that of potassium. Similar results were obtained by Sanogo and $a .^{31}$, with the extemporaneous infusion of a recipe used in traditional medicine for the treatment of hypertension. The results obtained with the aqueous extract of $C$. crepidioides showed that the CAI $>0.8$ thus the extract of the plant promotes a significant urinary excretion, as well as the saluretic activity in agreement to what was revealed by Ntchapda and al. ${ }^{19}$. These natriuretic, saliuretic and CAI effects of C. crepidioides might be beneficial in the management of some cases of hypertension, as they act through urinary excretion of part of the water and sodium in the blood. This will result in a decrease in blood volume, and therefore a drop-in blood pressure, stipulated by Sanogo and $a .^{31}$ with a "Nitrokoundang" recipe for the treatment of hypertension. 
Creatinine and urea were two markers of the kidney's role. Their metabolites which were the end products derived from protein metabolism had a generally constant concentration under normal conditions ${ }^{32}$. The urinary creatinine and urea concentration in animals treated with the extract increased significantly $(\mathrm{p}<0.05)$, or decreased significantly $(\mathrm{p}<0.05)$ in the blood, justifying the good functioning of kidneys in the elimination of metabolic wastes ${ }^{33}$. In fact, both creatinine and urea were eliminated from the blood through the process of glomerular filtration. In other words, the creatinine and urea concentrations in urine were ensured by the kidney. The determination of creatinine clearance is necessary to calculate the glomerular filtration rate, which decreases with the extract doses. This decrease may be due to increased $\mathrm{Na}^{+}$excretion, which tends to reduce GFR by increasing the $\mathrm{Na}^{+}$load available for $\mathrm{Na}^{+} / \mathrm{K}^{+}$exchange, which may further stimulate such exchange by hyperaldosteronism, causing the reduction of the blood volume ${ }^{34}$.

The biochemical parameters in the blood were higher in the animals treated with the extract and the reference substances compared to the control animals. However, the level of these parameters remains lower than the rate observed in the urine. This revealed that the aqueous extract not only causes a decrease in the blood volume, but also resulted in the elimination of electrolytes $(\mathrm{Na}+, \mathrm{K}+$ and $\mathrm{Cl}-)$, as well as elimination of metabolic wastes.

Increased serum transaminase levels had been reported to be caused by liver damage including hepatic cell necrosis, hepatitis, cirrhosis, hepatoxicity of certain drugs and myocardial infarction ${ }^{33}$. Results showed that the aqueous extract of $C$. crepidioides significantly $(\mathrm{p}<0.05)$ decrease the level of blood transaminase compared to control group. This decrease might reflect the protective role of plant against hepatotoxicity.
The results obtained are in agreement with those of Aniya and $a l^{11}$, who indicated that isochlorogenic acid, quercetin and kaempferol glycoside are active components of $C$. crepidioides with high free radical scavenging activity, a powerful antioxidant and a protector against hepatotoxicity induced by galactosamine (GalN) and lipopolysaccharide (LPS) or carbon tetrachloride (CCl4). This decrease could also be attributed to the presence of chemicals such as flavonoids, saponosides and alkaloids in the plant extract known for their antioxidant activity and protective hepatoprotection ${ }^{35}$. Similarly, the study conducted by Barrakat and al. ${ }^{36}$ has shown that diureses have antioxidant properties. The high concentration of transaminase in urine indicated that most of the body's wastes, including ASAT and ALAT are excreted in urine.

In conclusion, the results of the present study strongly suggest that $C$. crepidioides leaves' aqueous extract have potent and doseresponse diuretic properties in acute use in rats. These findings justify at least partly the use of this extract in folk medicine for the treatment of hypertension. Future studies aimed at identifying the active principles accounting for these effects of $C$. crepidioides leaves' aqueous extract may lead to the discovery of a potent diuretic, with potentially antioxidant properties.

\section{Acknowledgment}

We are profoundly grateful to the Institute of Medical Research and Medicinal Plants Studies (Cameroon), The authors also thank the Laboratory of the Medicinal Plants, Health and Galenic Formulation of the Department of Biological Sciences.

\section{Fundings}

The authors declare that they have received no funding for the research reported. 


\section{Availability of data and materials}

The datasets supporting the conclusions of this article are presented in this main paper. Plant materials used in this study were identified at the Cameroon National Herbarium where voucher specimens are deposited.

\section{Authors' contributions}

Ntchapda Fidèle supervised the study, improved the study mechanism and corrected the manuscript. Designed the study and was involved in the drafting and correction of the manuscript, analysis and interpretation of data.

Talla Ernest Rodrigue carried out the plant selection and collection and performed the experiments.

Bonabe Christian, Kemeta Azambou David Romain, Talla Emmanuel provided technical assistance in carrying out biochemical assays, contributed some reagents.

All the authors read the manuscript, critically revised it for important intellectual content and approved the final version of the manuscript.

\section{References}

1. Cloutier, L., Anne-Marie, L., Sophie, L., Maria, N. 2013. Pratique infirmiere : $\quad$ Traitement pharmacologique de l'HTA. Pratique clinique, 2-ACFA, partie 1. janvier / février / 2013 / vol.10 / $\mathrm{n}^{\circ} 1$; pp 37 https://www.oiiq.org/sites/default/files /uploads/periodiques/Perspective/vol1 0no1/07_Pratique_clinique_hta1.pdf

2. Kalchman C. M., 2016. Importance de la sensibilisation au risque cardiovasculaire et de l'évaluation des facteurs de risque en entreprise. Médecine humaine et pathologie. <dumas-01651101>. HAL Id: dumas01651101https://dumas.ccsd.cnrs.fr/du mas-01651101https://hal.inria.fr/ MEM-UNIV-PARIS5-MED/dumas01651101

3. Ojewole, J., Kamadyaapa, D. R., Musabayane, C. T., 2006. "Some in vitro and in vivo cardiovascular effects of Hypoxis hemerocallidea Fisch and CA Mey (Hypoxidaceae) corm (African potato) aqueous extract in experimental animal models," Cardiovasc J S Afr. 2006 JulAug;17(4):166-71. https://www.ncbi. nlm.nih.gov/pubmed/17001418

4. Zahoui, S.O., Zirihi, N.G., Soro, Y.T., Traore, F., 2010. Effet hypotenseur d'un extrait aqueux de Zanthoxylum zanthoxyloides (Lam.) Waterman (Rutaceae) Phytothérapie, Vol 8 (6), pp 359-369. https://www. researchgate. net/publication/ 226744159_Effet_hypotenseur_d'un_e xtrait_aqueux_de_Zanthoxylum_zanth oxyloides_Lam_Waterman_Rutaceae

5. Boua, B.B., Kouassi, K.C., Mamyrbékova-Békro, J.A, Kouamé, B.A., Békro, Y.A., 2013. Études Chimique et Pharmacologique de Deux Plantes Utilisées Dans le Traitement Traditionnel de L'hypertension Artérielle à Assoumoukro (Côte D'ivoire). European Journal of Scientific Research, ISSN 1450-216X/1450202X, Vol. 97 (3), pp.448-462, http://www.europeanjournalofscientifi cresearch.com

6. Kearney, PMJ., 2005. Global Burden of hypertension: analysis of worldwide data. The lancet, 365: 217223. http://www.ijpsonline.com/ articles/diuretic-activity-of-leaves-ofgarcinia-cambogia-in-rats.pdf 
7. Githa E. M., Mathew B., Shaneeb M. M. , and Nyanthara B. 2011. Diuretic Activity of Leaves of Garcinia Cambogia in Rats. Indian $\mathrm{J}$ Pharm Sci.; 73(2): 228-230. https://www. ncbi.nlm.nih.gov/pmc/articles/PMC40 80013/

8. Suresh B. S., Chitra C. K., Nimmagadda V. R. , Dasi J. M. B. , Vasant R. C., Aruna K., Karthik K. 2014. Evaluation of diuretic activity of alcoholic extract of roots of Cissampelos pareira in Albino Rats. J Clin Diagn Res. 8(5); HC01-HC04. doi: 10.7860/JCDR/2014/8192.4350; https://pdfs.semanticscholar.org/eb76/ d2f8aec3468b051b20b9c80e4ed48592 0b44.pdf

9. Konin, C., Adoh, M., Coulibaly, I., Kramoh, E., Safou, M., N'guetta, R., N'djessan, J.J., Koffi, J., (2006). L'observance thérapeutique et ses facteurs chez l'hypertendu. Cardiologie tropicale, 32, pp : 52 -57.

10. Omotayo, M.A., Avungbeto, O., Sokefun, O.O., Eleyowo, O.O., 2015. Antibacterial activity of Crassocephalum crepidioides (fireweed) and Chromolaena odorata (siam weed) hot aqueous leaf extract. Inter. J. Phar. and Biol Sci. Vol 5(2); 1: 114-122. https://ijpbs.com/ ijpbsadmin/upload/ijpbs_55942e15ef7 4e.pdf

11. Aniya, Y., Koyama, T., Miyagi, C., Miyahira, M., Inomata, C., Kinishita, S., Ichiba, T., 2005. L'elimination des radicaux libres et les actions hepatoprotective de l'herbe medicinale, Crassocéphallum crepidioides des iles d'Okinawa. Bull biol et pharm, 2: 19-23

12. Tomimori, K., Nakama, s., Kimura, R., Tamaki, K., Ishikawa, C., Mori, N., 2012. Antitumor activity and nitric oxide action of macrophage of
Crassocephalum crepidioides. BMC compl. and alter Med., 2: 11-19. https://bmccomplementalternmed. biomedcentral.com/articles/10.1186/1 472-6882-12-78

13. Chen, J.J., Lin, Y.H., Day, S.H., Hwang T.L., Chen, I.S. 2011. New benzenoids and anti-inflammatory constituents from Zanthoxylum nitidum. Food Chem.; 125(2): 282287. https://www.sciencedirect.com/ science/article/pii/S030881461001168 4

14. Henry, J. R., 1974. Clinical Chemistry, Principles and Technical. Haper and Row, $2^{\text {nd }}$ edition. pp: 541543. https://www.ncbi.nlm.nih.gov/ pmc/articles/PMC473238/

15. Ntchapda, F., Maguirgue, K., Michel, A. T. F., Olivier, M. P., Djedouboum, A. and Dimo, T., 2015. Evaluation of the diuretic effects of crude stem bark extraction of Zanthoxylum heitzii (Rutaceae) in Wistar rats. J Integr Med. 13(4), DOI: 10.1016/S20954964(15)60188-1. https://www.ncbi. nlm. nih. gov/pubmed/26343104

16. Prakash, B, Singh, P., Mishra, PK., Dubey, NK., 2011. Safety assessment of Zanthoxylum alatum Roxb. essential oil, its antifungal, antiaflatoxin, antioxidant activity and efficacy as antimicrobial in preservation of Piper nigrum L. fruits. Int J Food Microbiol., 2: 183-191.

17. Asmar, R., 2007. Pression artérielle. Régulation et épidémiologie. Mesures et valeurs normales. Néphrologie and Thérapeutique. 3(9):163-184. http://www.cmcv.org/upload/ publication/PA-

Regul\&epidemio_2007.pdf

18. Ntchapda, F., Barama, J., Kemeta Azambou, D.R., Seke Etet, P.F., Dimo, T. 2015. Diuretic and antioxidant activities of the aqueous 
extract of leaves of Cassia occidentalis (Linn.) in rats. Asian Pacific Journal of Tropical Medicine; 8(9): 685-693, http://dx.doi.org/10. 1016/j.apjtm.2015.07.030

19. Maghrani, M., Zeggwagh, N.A., Haloui, M., Eddouks, M., 2005. Acute diuretic effect of aqueous extract of Retama raetamin normal rats. $\mathrm{J}$ Ethnopharmacol; 99(1): 31-35.

20. Ntchapda, F., Djedouboum, A., Kom, B., Nana, P., Bonabe, C., Maguirgue, K., Talla, E, and Dimo, T. (2014). Diuretic Activity of the Aqueous Extract Leaves of Ficus glumosa Del. (Moraceae) in Rats. Hindawi Publishing Corporation. The Scientific World Journal. Volume 2014, Article ID 693803, 10 pages. doi: 10.1155/2014/693803. https://pdfs. semanticscholar.org/109d/

3a71b6297af3d867b4a3b60dbf8b5029 60f2.pdf

21. Lewy, J. E. and Windhager, E.E., 1968. Peritubular control of proximal fluid reabsorption in the rat kidney. Amer J Physiolo, pp: 214- 943. https://www.physiology.org/doi/abs/ 10.1152/ajplegacy.1968.214.5.943

22. Brenner, B.M., Falchuk, K.H., Keimowitz, R.L., $1969 . \quad$ The relationship between peritubular capillary protein concentration and fluid reabsorption by the renal proximal tubule. pp: 48. https://www. ncbi.nlm.nih.gov/pmc/articles/PMC32 2379/

23. Omale, J., Etubi, A., Friday, E., Godwin U., 2011. Antihypertensive effect of methanol extract of Napoleona imperialis (p.beauv) in adrenaline induced hypertensive albino rats. International Journal of Biochemistry Research and Review. 1(2):47-57..

24. Pedersen, M., Vajda, Z., StodkildeJorgensen, H., Nielsen, S, Frokiær, J.
2007. Furosemide increases water content in renal tissue. pp: 8 . https://www.physiology.org/doi/pdf/1 0.1152/ajprenal.00060.2006

25. DCEM1, 2007. Module cardiovasculaire. Les Diurétiques.doc. Faculté de médecine. pp: 3. http://udsmed.ustrasbg.fr/pharmaco/pdf/DCEM1_diur etiques.pdf

26. Jagannath, N., Shravani, P., Naga, T.P.A., Damodaram, G., Somashekar, S.C., 2017. Study of diuretic activity of aqueous extract of Amaranthus spinosus linn on rats, International Journal of Basic and Clinical Pharmacology. 1: 144-151. https://www.ijbcp.com/ index. php/ ijbcp/article/view/167

27. Delahaye, F.J.Y., Artigou, J.C., Daubert, Huques, M., 2008. Cardiology $\left(3^{\text {rd }}\right.$ édition), pp : 540.

28. Marhuenda, E.R., Calero, M., Gimenez, M.J.G., Remesal, M.D., Sanchez, M.J., 1986. Determination of the diuretic activity of the various preparations of Ononis speciosa Lag and Ononis mitissima. Annals of Pharmacology. 2: 455-460,.

29. Tahri, A., Yamani, S., Legssyeretal, A., 2000. "Acute diuretic, natriuretic and hypotensive effects of a continuous perfusion of aqueous extract of Urtica dioica in the rat," Journal of Ethnopharmacology. 3: 95-100. https://www.ncbi.nlm.nih.gov/pubmed $/ 11025144$

30. Gilani, SN., Khan, A.U., Gilani, A.H. Pharmacological basis for the medicinal use of Zanthoxylum armatum in gut, airways and cardiovascular disorders. Phytother Res. 2010; 24(4):553-558. https://www.ncbi.nlm.nih.gov/pubmed /20041426

31. Whitby, I.G., Smith, A.F., Beckett, G.J., 1988. Lecture note of clinical 
chemistry. 4th edition black well scientific publications, oxford. pp: 153-154

32. Géraldine, Y., and Hertig, A., 2012. Savoir interpréter une créatininémie pour apprécier la fonction rénale est essentiel. La revue du praticien médecine générale. http://www. larevuedupraticien.fr/sites/default/files /MG_2012_876_152.pdf

33. Dimo, T., Ntchapda, F., Barama, J., Kemeta Azambou, D.R., Seke Etet, P.F.; 2015. Diuretic and antioxidant activities of the aqueous extract of leaves of Cassia occidentalis (Linn.) in rats. Asian Pacific Journal of Tropical Medicine.2: $\quad 412-420$. https://www.ncbi.nlm.nih.gov/pubmed /26433651

34. Ramaiah, S. K., 2011. Preclinical safety assessment: current gaps, challenges and approaches in identifying translatable biomarkers of drug induced liver. Clinical Laboratory Medicine; pp: 161-72.

35. Choudhury, P. K and Jadhaw, S., 2013. Acute toxicity studies of methanolic Bark extract of Ficus racemosa and root extract of Cissampelos pareira. International journal of pharma and bio sciences. 2:1050-1055

36. Barakat, L. and Mahmoud, R. 2011. The antiatherogenic, renal protective and immunomodulatory effects of purslane, pumpkin and flax secds on hypercholesterolemic rats. J North Am., 1: 351-357. https://www.ncbi. nlm.nih.gov/pubmed/22362450

\section{How to cite this article:}

Ntchapda Fidèle, Talla Ernest Rodrigue, Bonabe Christian, Kemeta Azambou David Romain and Talla Emmanuel. 2019. Diuretic Activity of the Aqueous Extract Leaves of Crassocephalum crepidioides (Asteraceae) in Rats. Int.J.Curr.Microbiol.App.Sci. 8(04): 26492667. doi: https://doi.org/10.20546/ijcmas.2019.804.309 